\title{
OIL AND PROTEIN YIELD OF RAPESEED (Brassica Campestris L.) AS INFLUENCED BY INTEGRATED NUTRIENT MANAGEMENT
}

\author{
B. De ${ }^{1}$, A. C. Sinha \\ Department of Agronomy, Uttar Banga Krishi Viswavidyalaya \\ Pundibari Cooch Behar 736165, West Bengal, India
}

\begin{abstract}
A field experiment was conducted during 2007-2009 in the instructional farm of Uttar Banga Krishi Viswavidyalaya, West Bengal, India to find out the effect of integrated nutrient management on oil and protein yield of Rapeseed (Brassica campestris var. Yellow sarson). The experiment was laid out in randomized block design with 12 treatments viz., 100\% Recommended Dose Fertilizer (RDF) 60:30:30 Kg ha ${ }^{-1}$ of $\mathrm{N}: \mathrm{P}: \mathrm{K}\left(\mathrm{T}_{1}\right), 100 \% \mathrm{RDF}+$ Borax @ $10.0 \mathrm{Kg} \mathrm{ha}^{-1}$ $\left(\mathrm{T}_{2}\right)$, FYM @ $10.0 \mathrm{t} \mathrm{ha}^{-1}\left(\mathrm{~T}_{3}\right)$, Vermicompost @ $5.0 \mathrm{t} \mathrm{ha} \mathrm{h}^{-1}\left(\mathrm{~T}_{4}\right)$, Neemcake @ $5.0 \mathrm{t} \mathrm{ha}^{-1}\left(\mathrm{~T}_{5}\right)$, Poultry manure @ $5.0 \mathrm{t} \mathrm{ha}^{-1}\left(\mathrm{~T}_{6}\right), \mathrm{T}_{1}+\mathrm{FYM}$ @ $5.0 \mathrm{t} \mathrm{ha}^{-1}\left(\mathrm{~T}_{7}\right), \mathrm{T}_{1}+$ Vermicompost (VC) @ $2.5 \mathrm{t} \mathrm{ha}^{-1}\left(\mathrm{~T}_{8}\right), \mathrm{T}_{1}+$ Neemcake (NC) @ $2.5 \mathrm{t} \mathrm{ha}^{-1}\left(\mathrm{~T}_{9}\right), \mathrm{T}_{1}+$ Poultry Manure (PM) @ $2.5 \mathrm{t} \mathrm{ha}$ ${ }^{1}\left(\mathrm{~T}_{10}\right), 50 \%$ RDF+ FYM @ $2.5 \mathrm{t} \mathrm{ha}^{-1}$ + VC @1.25 t ha ${ }^{-1}+\mathrm{NC} @ 1.25 \mathrm{t}$ ha $^{-1}+$ PM @ 1.25 t ha $^{-1}\left(T_{11}\right)$ and Control $\left(T_{12}\right)$ and replicated thrice. Average results of oil and protein content and their respective yields was maximum (44.99 \& 29.84\% and 606.33 \& $402.11 \mathrm{~kg} \mathrm{ha}^{-1}$ respectively) in the crop fertilized with 50\% RDF + FYM @ $2.5 \mathrm{t} \mathrm{ha}^{-1}+$ VC@1.25 t ha ${ }^{-1}$ NC @ $1.25 \mathrm{t} \mathrm{ha}^{-1}+\mathrm{PM} @ 1.25 \mathrm{t} \mathrm{ha}^{-1}\left(\mathrm{~T}_{11}\right)$ followed by $T_{9}$ i.e. application of $T_{1}+$ Neemcake @ $2.5 \mathrm{t} \mathrm{ha}^{-1}$ (44.81 \& 29.22\% and 600.67 \& $391.50 \mathrm{~kg} \mathrm{ha}^{-1}$ respectively) and $\mathrm{T}_{8}$ i.e. application of $\mathrm{T}_{1}+$ Vermicompost @ $2.5 \mathrm{t} \mathrm{ha}^{-1}$ (44.24 \& 29.01 and 585.33 \& $383.67 \mathrm{~kg} \mathrm{ha}$ 1 respectively). Based on pooled data $\mathrm{T}_{11}$ treatment recorded maximum seed yield of $1347.68 \mathrm{~kg} \mathrm{ha}^{-1}$ which was statistically at par with $T_{9}\left(1340.47 \mathrm{~kg} \mathrm{ha}^{-1}\right)$, However, treatment $\mathrm{T}_{1}(100 \% \mathrm{RDF})$ showed highest BCR (3.85) due to low cost of cultivation.
\end{abstract}

Keywords: Crude seed, INM, neem cake, oil yield, poultry, protein yield, rapeseed, vermicompost

\footnotetext{
${ }^{1}$ Corresponding author email: ashimcsinha@indiatimes.com
} 


\section{INTRODUCTION}

Continuous use of chemical fertilizer in intensive cropping system is leading to imbalance of nutrients in soil, which has an adverse effect on soil health and ultimately low crop yields. Thus, imbalance use of mineral fertilizers have often led to fall of overall soil health of the country leading to a stagnation of food grain production in recent years in spite of consistent rise in fertilizer use (Abrol et al., 2000). This stagnation in agricultural productivity is often credited to degradation of soil due to various biotic and abiotic stresses inflicted on soil due to high input agriculture (Wang et al., 2003). Rapeseed oils are of high-value agricultural commodity for use in refined edible oil products and as renewable industrial or fuel oils. After oil extraction, rapeseed extraction meals contain a high-quality protein that can be used as a valuable animal feed. However, in comparison to other meals, oilseed rape also contains relatively high amounts of anti-nutritive fibre compounds, phenolic acids, phytate and glucosinolates (Wittkop et al., 2009). Fertilizer application has been a major strategy for soil nutrient replenishment. On the other hand, use of organic materials not only increase the nutrient status of the agricultural soils but also help improve various physical, chemical and biological properties of soils leading to betterment of soil quality and also to increased fertilizer use efficiency (Dick and Gregorich 2004). Again, continuous use of organics helps to build up soil humus and beneficial microbes besides improving the soil properties (De et al., 2009). This practice is aimed at ensuring that the cost of fertilizers are either escaped or at least substantially reduced. Hence, it is obvious that sustainable crop production could only be achieved in depleted tropical soils if both organic (plant and animal sources combined) and inorganic nutrient sources are properly used in integrated form. Therefore, a substitution and/or supplementation of major nutrients with a considerable proportion from organic manures or in combination for sustaining of high level of production, is necessary to boost up rapeseed production. Considering the above facts present investigation was undertaken to find out the effect of integrated nutrient management on oil and protein yield of Rapeseed (Brassica campestris var. Yellow sarson).

\section{MATERIALS AND METHODS}

The experiment was carried out at Instructional Farm of Uttar Banga Krishi Viswavidyalaya, Pundibari, Cooch Behar, West Bengal, India during the winter season of 2007, 2008 and 2009 respectively. The farm is situated at $26^{\circ} 19^{\prime} 86^{\prime \prime} \mathrm{N}$ latitude and $89^{\circ} 23^{\prime} 53^{\prime \prime}$ E longitude and at an altitude of 43 meters above mean sea level. The soil of the experimental site was sandy loam (62-65\% sand, $18 \%$ silt, 16$17 \%$ clay), with $0.52 \%$ organic carbon and acidic in nature ( $\mathrm{pH}$ of 5.42 ), low in available nitrogen (118 kg ha-1), medium in available phosphorus (24 $\mathrm{kg} \mathrm{ha}^{-1}$ ), available potash (76 $\mathrm{kg} \mathrm{ha}^{-1}$ ) and available boron (1.61 $\left.\mathrm{kg} \mathrm{ha}^{-1}\right)$. 
The experiment was laid out on $25^{\text {th }}, 17^{\text {th }}$ and $20^{\text {th }}$ day of October in 2007, 2008 and 2009 and harvested on $14^{\text {th }}, 24^{\text {th }}$ and $12^{\text {th }}$ day of March in 2008, 2009 and 2010 respectively. The experiment was done in a randomized block design with 12 treatments viz. 100\% Recommended Dose Fertilizer (RDF) 60:30:30 Kg ha ${ }^{-1}$ of N: P: K ( $\left.\mathrm{T}_{1}\right), 100 \% \mathrm{RDF}+$ Borax @10.0 Kg ha ${ }^{-1}\left(\mathrm{~T}_{2}\right), \mathrm{FYM} @ 10.0 \mathrm{t} \mathrm{ha}^{-1}\left(\mathrm{~T}_{3}\right)$, Vermicompost@5.0 t ha ${ }^{-1}\left(\mathrm{~T}_{4}\right)$, Neemcake@5.0 t ha ${ }^{-1}\left(\mathrm{~T}_{5}\right)$, Poultry manure @5.0 t $\mathrm{ha}^{-1}\left(\mathrm{~T}_{6}\right), \mathrm{T}_{1}+\mathrm{FYM} @ 5.0 \mathrm{t} \mathrm{ha}^{-1}\left(\mathrm{~T}_{7}\right), \mathrm{T}_{1}+$ Vermicompost (VC) @ $2.5 \mathrm{tha}^{-1}\left(\mathrm{~T}_{8}\right), \mathrm{T}_{1}+$ Neemcake (NC)@2.5 tha $\mathrm{t}^{-1}\left(\mathrm{~T}_{9}\right), \mathrm{T}_{1}+$ Poultry manure (PM) @ $2.5 \mathrm{t} \mathrm{ha}^{-1}\left(\mathrm{~T}_{10}\right), 50 \%$ RDF+FYM@2.5 t ha ${ }^{-1}$ + VC@1.25 t ha ${ }^{-1}$ + NC @1.25 t ha ${ }^{-1}$ + PM @ 1.25 t ha ${ }^{-1}$ $\left(\mathrm{T}_{11}\right)$ and Control $\left(\mathrm{T}_{12}\right.$ and replicated thrice. Well decomposed farmyard manure, vermicompost, neemcake, poultry manure with nitrogen, phosphorus and potassium in the form of urea, SSP, MOP and borax were applied to the soil as per treatments. Full dose of phosphorus, potash and half of the recommended dose of nitrogen and borax were applied as basal dose. Rest half of the recommended dose of nitrogen was applied as top dressing at 21 DAS (days after sowing) after completion of the first weeding. One irrigation was given to rapeseed crop 45 DAS. Rapeseed cultivar "NC1 " was sown at a spacing of $30 \mathrm{~cm} \times 10 \mathrm{~cm}$.

Nitrogen content of the plant parts were analyzed separately after harvest by modified Kjeldahl method (Jackson. 1967) and was multiplied by their respective dry weights to work out uptake of nutrients of different parts as well as the plant as a whole and represented by the standard units. The $\mathrm{N}, \mathrm{P}$ and $\mathrm{K}$ content of farm yard manure ( $0.43,0.16$ and $0.44 \%)$, vermicompost $(0.75,0.26$ and $0.03 \%)$, poultry manure (2.13, 1.11 and $1.09 \%)$ and neemcake (1.73, 0.66 and $0.94 \%)$ were analyzed subsequently. The percentage of oil in rapeseed grains were estimated by adopting Soxhlet Ether Extraction Method (1970) where 5 g grain samples for each treatment combinations was used. Oil yield $\mathrm{kg} \mathrm{ha}^{-1}(\mathrm{Oy})$ was estimated by multiplying seed yield (Sy) with oil content . Whereas, crude seed-protein content (CSPC) of rapeseed was calculated by multiplying nitrogen content (\%) of seeds, by a factor, 6.25.

The data collected from the field and laboratory experiments were subjected to statistical analysis and the treatment variations were tested for significance (Gomez and Gomez, 1984) at 5\% level.

\section{Yield components of rapeseed}

\section{RESULTS AND DISCUSSION}

The yield components of rapeseed were influenced significantly by different INM treatments involving 50 and $100 \%$ of recommended dose of $\mathrm{N}, \mathrm{P}$, and $\mathrm{K}$ in combination with organics than the sole application of organics over control treatment. The highest numbers of siliqua plant ${ }^{-1}$ (189.47) were recorded with the integrated nutrient application of 50\% RDF+ FYM@2.5 t ha ${ }^{-1}$ + VC @1.25 t ha ${ }^{-1}+$ NC@1.25 t ha ${ }^{-1}+$ PM @ $1.25 \mathrm{t} \mathrm{ha}^{-1}\left(\mathrm{~T}_{11}\right)$ (Table-1). It was indicative of the fact that during the three years of experiment, Neemcake, Vermicompost and Poultry manure 
in conjunction with FYM, nitrogen, phosphorus, potassium exhibited their role in various physiological functions, movement of growth regulators within the plant, germination and growth of pollen grains and pollen tubes (Sakal and Singh, 1995). Similarly, the number of grains siliqua ${ }^{-1}(7.19)$, length of siliqua $(21.16 \mathrm{~cm})$ and 1000- seed weight (3.08 g) were also maximum with the same integrated nutrient management of rapeseed followed by $\mathrm{T}_{9}\left(\mathrm{~T}_{1}+\right.$ Neemcake (nc) @ $\left.2.5 \mathrm{t} \mathrm{ha}^{-1}\right), \mathrm{T}_{8}\left(\mathrm{~T}_{1}+\right.$ Vermicompost (VC)@2.5 t ha $\left.{ }^{-1}\right) \& \mathrm{~T}_{10}\left(\mathrm{~T}_{1}+\right.$ Poultry manure (PM) @ $\left.2.5 \mathrm{t} \mathrm{ha}^{-1}\right)$, which were statistically at par. With the successive addition of FYM, Vermicompost, Neemcake and Poultry manure or their different combinations with the recommended dose of N, P, K, S, B (50 or 100\%) and consecutively for the peceeding three years, the length of siliqua were increased over control as well as over recommended dose of $\mathrm{N}, \mathrm{P}, \mathrm{K}, \mathrm{S}, \mathrm{B}$ either alone or with borax and sole application of organics. Gangasaran and Kinra (1997),) also reported similar findings about yield components. It would further be seen that higher weight of 1000 -seeds were obtained in the treatments where $\mathrm{N}, \mathrm{P}, \& \mathrm{~K}$ level was more or less optimum through inorganic or organic sources. It was not ostensible that boron, zinc as well as sulphur favored fruit-setting and grain filling of rapeseed by improving the source-sink relationships and photosynthate partitioning.

\section{Oil content}

Variations in oil content were not much pronounced. Pooled analysis (Table-2) revealed that maximum seed oil content of rapeseed (44.99\%) was recorded under $\mathrm{T}_{11}$ (50\% RD + FYM @ $2.5 \mathrm{t} \mathrm{ha}^{-1}+\mathrm{VC} @ 1.25 \mathrm{t} \mathrm{ha}^{-1}+\mathrm{NC} @ 1.25 \mathrm{t} \mathrm{ha}^{-1}+\mathrm{PM} @$ $1.25 \mathrm{t} \mathrm{ha}^{-1}$ ) followed by $\mathrm{T}_{9}(44.81 \%), \mathrm{T}_{8}(44.24 \%)$ and $\mathrm{T}_{10}(44.12 \%)$. The supplementation of FYM, Vermicompost, Neemcake and Poultry manure and their different combinations with 50 and $100 \%$ of recommended dose of nitrogen, phosphorus and potash, increased the oil content of rapeseed during the experimentation. Chauhan et al., (1996) also reported increase in oil content in seed with the application of organics in combination or alone. The essential elements like sulphur, boron and zinc were present with a considerable amount in FYM, Vermicompost, Neemcake and Poultry manure which, probably promotes the synthesis of oil with the receipt of energy from ATP (adenosine tri phosphate). These results corroborated the findings of Tomar et al., (1996) and Singh and Singh (2006).

\section{Oil yield}

Maximum oil yield of $606.33 \mathrm{~kg} \mathrm{ha}^{-1}$ was also obtained with integrated nutrient management of 50\% RD + FYM @2.5 t ha ${ }^{-1}+$ VC @1.25 t ha ${ }^{-1}+$ NC @ 1.25 tha $^{-1}+$ PM@ $1.25 \mathrm{t} \mathrm{ha}^{-1}\left(\mathrm{~T}_{11}\right)$. But, it was statistically at par with $\mathrm{T}_{9}(100 \%$ of RD + Neemcake@2.5 $\mathrm{t} \mathrm{ha}^{-1}$ ). The wider variations in oil yield were largely due to differences in seed yield of rapeseed because oil yield is the resultant of seed yield and oil content. Satyajeet et al., (2007) studied the residual effect on the Indian mustard (cv. RH-30) crop after pearl millet where the application of vermicompost and biofertilizer to the previous pearl millet crop improved the yield characteristics of the succeeding Indian mustard. Tomar et al., (1996) obtained same findings. 


\section{Crude seed-protein content (CSPC)}

Crude seed-protein content increased with the application of higher level of nutrients particularly nitrogen, phosphorus, potassium. Crude seed-protein content (CSPC) was maximum (29.84\%)with T 11 (50\% RD + FYM @ 2.5 t ha $^{-1}+$ VC @ 1.25 $\mathrm{t} \mathrm{ha}^{-1+} \mathrm{NC} @ 1.25 \mathrm{t} \mathrm{ha}^{-1}+\mathrm{PM} @ 1.25 \mathrm{t} \mathrm{ha}^{-1}$ ) which was statistically at par with $\mathrm{T}_{9}$ (100\% of RD + Neemcake @ $2.5 \mathrm{t} \mathrm{ha}^{-1}$ ) and $\mathrm{T}_{8}$ (100\% of RD + Vermicompost @ 2.5 $\mathrm{t} \mathrm{ha}{ }^{-1}$ ) (Table-2). Lower percent of crude proteins were recorded with 100\% recommended dose alone and with borax and sole application of organic. Since nitrogen plays an important role in the synthesis of amino-acids which constitute building blocks of protein, it resulted in higher protein content in seeds at 50\% RD + FYM@2.5 t ha $a^{-1}+$ VC@1.25 tha ${ }^{-1}+$ NC@1.25 t ha ${ }^{-1}+$ PM @1.25 t ha'.1.FYM, being well decomposed high quality manure contained $0.5 \%$ of N. Similar results were reported by Mandal and Sinha (2004).

\section{Crude seed-protein yield}

The highest crude seed protein yield (402.11 kg ha-1) was also recorded with $\mathrm{T}_{11}$ which was statistically at par with the protein yield of $\mathrm{T}_{9}(100 \%$ of $\mathrm{RD}+$ Neemcake @ $2.5 \mathrm{t} \mathrm{ha}^{-1}$ ) and $\mathrm{T}_{8}\left(100 \%\right.$ of RD + Vermicompost @ $2.5 \mathrm{t} \mathrm{ha}^{-1}$ ) (Table2). Higher protein yields were obtained at 100 and $50 \%$ level of recommended dose combined with FYM, Vermicompost, Neemcake and Poultry manure than control (without fertilizers). Higher protein yield was ascribed in those treatment combinations where seed yield was higher. Similar findings were reported by Mandal and Sinha (2004).

\section{Cost Benefit Analysis}

Maximum rapeseed yield (13.48 $\mathrm{q} \mathrm{ha}^{-1}$ ) was obtained by integrated nutrient managent of 50\% RD + FYM@2.5 tha ${ }^{-1}+$ VC @1.25 tha ${ }^{-1}+\mathrm{NC} @ 1.25 \mathrm{tha}^{-1}+\mathrm{PM}$ @ $1.25 \mathrm{t} \mathrm{ha}^{-1}\left(\mathrm{~T}_{11}\right)$ whereas highest BCR (3.85) was achieved with the application of $100 \%$ Recommended dose $\left(60: 30: 30 \mathrm{Kg} \mathrm{ha}^{-1}\right.$ of $\left.\mathrm{N}: \mathrm{P}: \mathrm{K}\right)$ due to low cost of cultivation $\left(\mathrm{T}_{1}\right)$. Higher price of neemcake $\left(\mathrm{Rs} 10 \mathrm{Kg}^{-1}\right)$ leads to increased treatment cost in turn elevating the investment cost as a result incurred loss of Rs 36385.35 ha $^{-}$

${ }^{1}$. The minimum net return was obtained with $\mathrm{T}_{9}(100 \%$ of RD + Neemcake @ $2.5 \mathrm{t}$ $\mathrm{ha}^{-1}$ ). Among the treatment combinations the maximum higher net return of Rs 24,904 ha $^{-1}$ was obtained from treatment $T_{1}$ (100\% Recommended dose), whereas higher yield treatment $\mathrm{T}_{11}$ earned lower return of Rs $11113.48 \mathrm{ha}^{-1}$. This indicated that the crop had received the most congenial nutrient status in soil at its vegetative and reproductive organs of rapeseed when these treatments were applied. These results are corroborative of the findings of Dubey and Khan (1993). 


\section{CONCLUSION}

Combination of all the organic sources with inorganic nutrients gives higher oil as well as seed yield of rapeseed in addition with the improvement in soil health but recommendations could only be made by judging from the economic point of view where treatment consisting of $100 \%$ recommended fertilizer along with Borax showed higher benefit due to lower cost. Thus, farmers who produce or recycle their own organic sources for their field application could only be benefited in the long run.

\section{REFERENCES}

Abrol, I.P., Bronson, K.F., Duxbury, J.M. and Gupta, R.K. 2000. Long term fertility experiments in rice-wheat cropping systems. Rice-Wheat Consortium paper series no 6, New Delhi, India.

Chauhan, D.R., Paroda, S. and Ram, M. 1996. Response of Indian mustard (Brassica juncea) to biofertilizers, S and N fertilization. Indian J. Agron., 41 (4) : 621-623.

Dick, W.A. and Cregorich, E.G. 2004. Developing and maintaining soil organic matter levels. (In) Managing Soil Quality: Challenges in Modern Agriculture

Gangasaran. and. Kinra, K.L. 1979. Responses of rai (Brassica juncea) to nitrogen with and without P and K. J. Res., 9: 6-8.

Gomez, K.A. and Gomez, A.A. 1984. Statistical Procedures for Agricultural Research. John Wiley \& Sons, New York, USA.680.

Jackson, M.L. 1967. Soil Chemical Analysis. Prentice Hall of India Pvt. Ltd., New Delhi

Mandal, K.G. and Sinha, A.C. 2004. Nutrient management effects on light interception, photosynthesis, growth, dry-matter production and yield of Indian mustard (Brassica juncea). J. Agron and Crop Sci., 190 (2): 119-129.

Sakal, R. and Singh, A.P. 1995. Boron research and agricultural production. In Micronutrient Research and Agricultural production. Ed. H.L. S Tandon. Fertilizer development and consultation organization (FDCO), New Delhi. pp. 1-31.

Satyajeet., Nanwal, R.K. and Yadav, V.K. 2007. Residual effect of integrated nutrient management on Indian mustard under pearlmillet (Pennisetum glaucum) - mustard (Brassica juncea) cropping sequence. Brassica., 9(1/4): 79-82.

Singh, R. and Singh, S.K. 2006. Evaluation of yield and quality aspects of Indian mustard (Brassica juncea L. Czernj \& Cosson) under integrated nutrient management. Ann. Agril. Res., 27(3): 220-223.

Tomar, T.S., Tomar, T.V.S., Kumar, S., Tomar, S., Singh, M. and Singh, S. 1996. Response of Indian mustard (Brassica juncea L.) varieties to nitrogen, phosphorus and potassium fertilizers. Indian J. Agron., 41 (4): 624-26.

Wang, W.J., Dalal, R.C., Moody, P.W. and Smith, C.J. 2003. Relationship of soil respiration to microbial biomass, substrate availability and clay content. Soil Bio. and Biochem., 35: 273-84.

Wittkop, B., Snowdon, R.J. and Friedt, W. 2009. Status and perspectives of breeding for enhanced yield and quality of oilseed crops for Europe. Euphytica 170:131-140. 
Table 1: Effect of integrated nutrient management on yield components of rapeseed (Pooled of 3 years data)

\begin{tabular}{ccccc}
\cline { 2 - 5 } Treatments & Siliqua plant $^{-\mathbf{1}}$ & $\begin{array}{c}\text { Siliqua length } \\
\text { (cm) }\end{array}$ & $\begin{array}{c}\text { No. of seed }_{\text {siliqua }^{-1}} \\
\mathrm{~T}_{1}\end{array} \mathrm{c}$ & $\begin{array}{c}\text { Test weight } \\
\text { (g) }\end{array}$ \\
$\mathrm{T}_{2}$ & 120.95 & 5.53 & 17.34 & 2.81 \\
$\mathrm{~T}_{3}$ & 95.72 & 4.75 & 18.42 & 2.85 \\
$\mathrm{~T}_{4}$ & 118.92 & 5.40 & 15.67 & 2.36 \\
$\mathrm{~T}_{5}$ & 112.76 & 5.37 & 17.06 & 2.74 \\
$\mathrm{~T}_{6}$ & 103.37 & 5.15 & 16.64 & 2.67 \\
$\mathrm{~T}_{7}$ & 130.48 & 5.68 & 16.41 & 2.59 \\
$\mathrm{~T}_{8}$ & 137.10 & 6.57 & 18.68 & 2.90 \\
$\mathrm{~T}_{9}$ & 153.09 & 6.76 & 19.36 & 2.95 \\
$\mathrm{~T}_{10}$ & 134.84 & 5.77 & 20.05 & 3.01 \\
$\mathrm{~T}_{11}$ & 189.74 & 7.19 & 19.05 & 2.93 \\
$\mathrm{~T}_{12}$ & 80.64 & 3.62 & 21.16 & 3.08 \\
\hline $\mathrm{S} . \mathrm{E} \pm$ & 1.76 & 0.04 & 14.10 & 2.27 \\
C.D (p=0.05) & 3.65 & 0.09 & 0.09 & 0.02 \\
\hline
\end{tabular}

$\mathbf{T}_{\mathbf{1}}=100 \%$ Recommended dose (60:30:30 Kg/ha of N: P: K) $\mathbf{T}_{2}=100 \%$ Recommended dose + Borax @ $7.5 \mathrm{Kg} \mathrm{ha}{ }^{-1} ; \mathbf{T}_{3}=$ FYM @10.0 t ha ${ }^{-1} ; \mathbf{T}_{4}=$ Vermicompost @ $5.0 \mathrm{t} \mathrm{ha}^{-1} ; \mathbf{T}_{5}=$ Neemcake @ $5.0 \mathrm{t} \mathrm{ha}^{-1} ; \mathbf{T}_{\mathbf{6}}=$ Poultry manure@5.0 tha ${ }^{-1} ; \mathbf{T}_{7}=\mathrm{T}_{1}+\mathrm{FYM} @ 5.0 \mathrm{t} \mathrm{ha}^{-1} ; \mathbf{T}_{8}=\mathrm{T}_{1}+$ Vermicompost @ $2.5 \mathrm{t} \mathrm{ha}^{-1} ; \mathrm{T}_{9}=\mathrm{T}_{1}+$ Neemcake@ $2.5 \mathrm{t} \mathrm{ha}^{-1} ; \mathbf{T}_{\mathbf{1 0}}=\mathrm{T}_{1}+$ Poultry manure@ $2.5 \mathrm{t} \mathrm{ha}^{-1} ; \mathbf{T}_{\mathbf{1 1}}=50 \%$ Recommended dose + FYM @ 2.5 t ha $^{-1} \mathrm{a}$ + VC @1.25 t ha ${ }^{-1}$ NC @1.25 t ha ${ }^{-1}+$ PM @ 1.25 t ha $^{-1} ; \mathbf{T}_{12}=$ Control. 
Table 2: Effect of integrated nutrient management on oil content (OC), oil yield (OY), crude seed protein content (CSPC) and crude seed protein yield (CSPY) of rapeseed (Pooled of 3 years)

\begin{tabular}{c|c|c|c|c}
\hline Treatments & OC (\%) & $\begin{array}{c}\text { OY } \\
\left(\mathbf{K g ~ h a}^{-\mathbf{1}} \mathbf{)}\right.\end{array}$ & $\mathbf{C S P C ~ ( \% )}$ & $\begin{array}{c}\mathbf{C S P Y} \\
\mathbf{( K g ~ h a}^{-\mathbf{1}} \mathbf{)}\end{array}$ \\
\hline $\mathrm{T}_{1}$ & 43.28 & 539.33 & 24.47 & 304.96 \\
$\mathrm{~T}_{2}$ & 43.55 & 550.67 & 24.84 & 314.07 \\
$\mathrm{~T}_{3}$ & 38.70 & 308.67 & 23.61 & 188.26 \\
$\mathrm{~T}_{4}$ & 41.72 & 425.33 & 24.32 & 247.91 \\
$\mathrm{~T}_{5}$ & 40.62 & 372.00 & 24.24 & 221.99 \\
$\mathrm{~T}_{6}$ & 39.59 & 334.00 & 24.18 & 203.83 \\
$\mathrm{~T}_{7}$ & 43.79 & 565.67 & 25.46 & 328.81 \\
$\mathrm{~T}_{8}$ & 44.24 & 585.33 & 29.01 & 383.67 \\
$\mathrm{~T}_{9}$ & 44.81 & 600.67 & 29.22 & 391.50 \\
$\mathrm{~T}_{10}$ & 44.12 & 577.67 & 27.94 & 365.52 \\
$\mathrm{~T}_{11}$ & 44.99 & 606.33 & 29.84 & 402.11 \\
$\mathrm{~T}_{12}$ & 37.02 & 280.67 & 14.99 & 113.37 \\
\hline $\mathrm{S} . \mathrm{E} \pm$ & 0.19 & 3.14 & 0.25 & 2.21 \\
C.D (p=0.05) & 0.41 & 6.51 & 0.53 & 4.59 \\
\hline
\end{tabular}

$\mathbf{T}_{1}=100 \%$ Recommended dose (60:30:30 Kg/ha of N: P: K) $\mathbf{T}_{2}=100 \%$ Recommended dose + Borax @ $7.5 \mathrm{Kg} \mathrm{ha}^{-1} ; \mathbf{T}_{3}=$ FYM @10.0 tha ${ }^{-1} ; \mathbf{T}_{4}=$ Vermicompost @ $5.0 \mathrm{t} \mathrm{ha}^{-1} ; \mathbf{T}_{5}=$ Neemcake @ $5.0 \mathrm{t} \mathrm{ha}^{-1} ; \mathbf{T}_{6}=$ Poultry manure @5.0 t ha ${ }^{-1} ; \mathbf{T}_{7}=\mathrm{T}_{1}+\mathrm{FYM} @ 5.0 \mathrm{tha}^{-1} ; \mathbf{T}_{\mathbf{8}}=\mathrm{T}_{1}+$ Vermicompost @ $2.5 \mathrm{t} \mathrm{ha}^{-1} ; \mathrm{T}_{9}=\mathrm{T}_{1}+$ Neemcake@2.5 t ha ${ }^{-1} ; \mathbf{T}_{10}=\mathrm{T}_{1}+$ Poultry manure@2.5 $\mathrm{t} \mathrm{ha}^{-1} ; \mathbf{T}_{11}=50 \%$ Recommended dose + FYM @ $2.5 \mathrm{t} \mathrm{ha}^{-1}+\mathrm{VC} @ 1.25 \mathrm{tha}^{-1}+\mathrm{NC} @ 1.25 \mathrm{tha}^{-1}+\mathrm{PM} @ 1.25 \mathrm{t} \mathrm{ha}^{-1} ; \mathbf{T}_{12}=$ Control. 
Table 3: Effect of integrated nutrient management on seed yield, net return and BCR (Pooled of 3 years)

\begin{tabular}{lccccc}
\hline Treatments & $\begin{array}{c}\text { Seed yield } \\
\left(\mathbf{q ~ h a} \mathbf{~ h}^{-1}\right)\end{array}$ & $\begin{array}{c}\text { Gross margin } \\
\left(\text { Rs ha }^{-1}\right)\end{array}$ & $\begin{array}{c}\text { Total cost } \\
\left.\text { (Rs ha }^{-1}\right)\end{array}$ & $\begin{array}{c}\text { Net return } \\
\left.\text { (Rs ha }^{-1}\right)\end{array}$ & $\begin{array}{c}\text { Benefit } \\
\text { cost ratio }\end{array}$ \\
\cline { 2 - 6 } $\mathrm{T}_{1}$ & 1246.24 & 37387.32 & 15419 & 21968.32 & 3.85 \\
$\mathrm{~T}_{2}$ & 1264.54 & 37936.30 & 17819 & 20117.30 & 3.26 \\
$\mathrm{~T}_{3}$ & 797.49 & 23924.64 & 17565 & 6359.64 & 1.72 \\
$\mathrm{~T}_{4}$ & 1019.44 & 30583.35 & 31365 & -781.65 & 0.95 \\
$\mathrm{~T}_{5}$ & 915.99 & 27479.65 & 63865 & -36385.35 & -0.14 \\
$\mathrm{~T}_{6}$ & 843.63 & 25309.00 & 43865 & -18556.00 & 0.15 \\
$\mathrm{~T}_{7}$ & 1291.87 & 38756.12 & 17269 & 21487.12 & 3.49 \\
$\mathrm{~T}_{8}$ & 1323.09 & 39692.62 & 24169 & 15523.62 & 2.28 \\
$\mathrm{~T}_{9}$ & 1340.47 & 40214.20 & 40419 & -204.80 & 0.99 \\
$\mathrm{~T}_{10}$ & 1309.21 & 39276.15 & 30419 & 8857.15 & 1.58 \\
$\mathrm{~T}_{11}$ & 1347.68 & 40430.48 & 29317 & 11113.48 & 1.76 \\
$\mathrm{~T}_{12}$ & 758.16 & 22744.78 & 13865 & 8879.78 & 2.28
\end{tabular}

$\mathbf{T}_{\mathbf{1}}=100 \%$ Recommended dose (60:30:30 Kg/ha of N: P: K); $\mathbf{T}_{2}=100 \%$ Recommended dose + Borax @ $7.5 \mathrm{Kg} \mathrm{ha}^{-1} ; \mathbf{T}_{3}=\mathrm{FYM} @ 10.0 \mathrm{t} \mathrm{ha}^{-1} ; \mathbf{T}_{\mathbf{4}}=$ Vermicompost @ $5.0 \mathrm{t} \mathrm{ha}^{-1} ; \mathbf{T}_{5}=$ Neemcake @ $5.0 \mathrm{t} \mathrm{ha}^{-1} ; \mathbf{T}_{\mathbf{6}}=$ Poultry manure@5.0 t ha ${ }^{-1} ; \mathbf{T}_{7}=\mathrm{T}_{1}+\mathrm{FYM} @ 5.0 \mathrm{t} \mathrm{ha}^{-1} ; \mathbf{T}_{\mathbf{8}}=\mathrm{T}_{1}+$ Vermicompost @ $2.5 \mathrm{t} \mathrm{ha}^{-1} ; \mathrm{T}_{9}=\mathrm{T}_{1}+$ Neemcake@2.5 tha ${ }^{-1} ; \mathbf{T}_{10}=\mathrm{T}_{1}+$ Poultry manure @ $2.5 \mathrm{t} \mathrm{ha}^{-1} ; \mathbf{T}_{\mathbf{1 1}}=50 \%$ Recommended dose + FYM @ 2.5 t ha $^{-1} \mathrm{a}$ + VC @1.25 tha ${ }^{-1}$ NC @1.25 t ha ${ }^{-1}$ PM @ 1.25 t ha $^{-1} ; \mathbf{T}_{12}=$ Control.

Cost of FYM (4 tonnes) = Rs. 1850, Urea= Rs. 5.02, Borax (powdered) = Rs. 300

$\mathrm{SSP}=$ Rs. $3.52 \mathrm{~kg}^{-1} \quad$ Vermicompost= Rs. $3.5 \mathrm{~kg}^{-1} \mathrm{MOP}=$ Rs. $4.62 \mathrm{~kg}^{-1}$

Neemcake= Rs. $10 \mathrm{~kg}^{-1}$ Poultry manure= Rs. $6 \mathrm{~kg}^{-1}$ 